\title{
Increasing Learning Result Of Student IV Students Using Constructiveness Approach
}

\author{
Zaiyasni \\ Padang State University, Padang, Indonesia \\ Corresponding e-mail: dra.zaiyasni@yahoo.co.id
}

ABSTRACT

The background research that has not fully maximized learning outcomes The aim of this study was to describe the learning outcome with a constructivist approach. This type of research is classroom action research with qualitative and quantitative approaches. Research conducted at SDN 11 Piai Tangah District of Kota Padang Pauh with research subjects, namely the class teacher and grade IV. The results showed an increase from the first cycle of $79.6 \%$ to $86.3 \%$.

Keywords: Learning Science, Approach Constructivism

\section{INTRODUCTION}

Based on the results of observations and interviews of researchers with fourth grade teacher SDN 11 Piai Tangah Pauh sub district Padang, on science lesson less teachers involve students to be active in learning because the learning activities are dominated by teachers. In addition, teachers do not involve students to develop students' scientific thinking skills, such as those that occur when students express their opinions are less responsive, the teacher answers the problem. From the lesson, it is seen that the teacher does not develop the thinking ability of the students. While learning science in SD is expected to provide opportunities for students to cultivate students' curiosity, develop students' questioning skills, and improve students' ability to seek answers based on evidence, then science lessons in elementary school also require students to be active in learning, because the science lesson is a series Scientific process activities. [4] "IPA in SD should open the opportunity to nurture students' natural curiosity. This will help them develop the ability to ask questions and seek answers based on evidence and develop a scientific way of thinking. "

As a result of the way of learning by the teacher makes the students less able to develop their knowledge both think critically, creatively and systematically in learning so that the students' learning outcomes are low. Evident from the results learning obtained by students is not as expected, from 24 students who are able to reach KKM that is 75 only 10 people $(42 \%)$ while 14 people $(58 \%)$ others are not complete. The average class is 69.6. This means it still has not achieved the expected result.

To overcome the problems mentioned above, teachers should be able to choose the right learning approach. One approach to learning that is able to build new knowledge in students is the constructivism approach. According to Vienna (2008: 118) "Constructivism approach is the process of constructing or composing new knowledge in the cognitive structure of students based on experience".

The advantages of constructivism approach by Driver [4] states the advantages of constructivism approach are:

1) giving students the opportunity to express ideas explicitly by using their own language, ideas with friends and encouraging students to explain ideas, 2) providing experiences related to ideas that students already have, 3) giving students opportunities to think about experiences So that students think creatively, imaginatively, encourage reflection on theories and models, introduce the ideas of science at the right time, 4) give students the opportunity to try new ideas, 5) encouraging students to think about changing ideas of students after learning about their students 'abilities and providing opportunities to identify students' change of ideas, 6) providing a conducive learning environment that supports students expressing ideas, listening to each other and avoiding the impression always.

So constructivism approach is a learning approach that can overcome the problems found during observation that is able to develop students' critical, creative, and systematic thinking skills, develop students' ability in problem solving, and develop students' ability to actively build their own knowledge. By looking at the many advantages of using the constructivism approach, the researcher intends to conduct a class action research (PTK) with the title "Improving Results of Science Class IV Student Learning Using Constructivism Approach". 
The purpose of this research in general is to describe the increase of learning result of Natural Science (IPA) by using constructivism approach in class IV SDN 11 Piai Tangah Kecamatan Pauh Kota Padang. Specifically, this study aims to describe: (1) implementation of science learning using constructivism approach in class IV SDN 11 Piai Tangah Pauh sub-district Padang and (2) science learning outcomes using constructivism approach in class IV SDN 11 Piai Tangah Kecamatan Pauh Padang city.

\section{METHOD}

This research is a Classroom Action Research (PTK) using a quantitative and qualitative approach. According to Bogdan [2] "a qualitative approach is used in a research procedure that produces descriptive data in the form of written or oral words and observed behavior of persons or sources of information".

This research was carried out at SDN 11 Piai Tangah Kecamatan Pauh Kota Padang. Subjects in this study were teachers and fourth graders of SDN 11 Piai Tangah Kecamatan Pauh Kota Padang with a total of 24 students consisting of 10 male students and 14 female students enrolled in second semester of academic year 2015/2016. The source of this research data comes from the observation process of science learning activities using constructivism approach in class IV SDN 11 Piai Tangah District Pauh Padang City. The data were collected by observation, interview and test. This research was conducted in second semester of academic year 2015/2016 (January to June 2016) with details of action that is first cycle of first meeting on 13 April 2016 and second meeting on 20 April 2016. Implementation of cycle II first meeting on 27 April 2016 and the second meeting on May 04, 2016.

The data obtained in the study were analyzed using a qualitative data analysis model begins by reviewing the data collection until all data collected. As Rochiati (2007: 135) puts it, "the analysis by researchers is to make decisions about how to display data in tables, matrices, or story forms".

\section{RESULT}

\section{Cycle I}

\section{a. Planning}

This learning planning is arranged collaboratively between researcher with fourth grade teacher of SDN 11 Piai Tangah Subdistrict of Pauh Padang. This planning is developed and developed based on Education Unit Level Curriculum (KTSP) on science subjects class IV semester II. Lesson planning is presented 1 $\mathrm{x}$ meeting with time allocation $3 \times 35$ minutes.

The learning materials that are carried out in cycle I are obtained from the relevant package and supporting books. In accordance with the basic competencies that have been analyzed, the expected indicators achieved in the first cycle of learning are the students can 1) run the erosion process experiment, 2) mention the definition of erosion, 3) identify causes of erosion to the land and 4) Prevention of erosion to the land. Indicators to be achieved at the second meeting are the students can 1) run the abrasion process, 2) mention the meaning of abrasion, 3) identify the causes of abrasion to the land and 4) provide opinions in disabling prevention efforts from abrasion against mainland.

Prior to the learning implementation, the researcher prepares the lesson plan, LKS, and evaluation sheet consisting of 10 multiple choice questions and 5 essay questions and evaluation key that will be used in the lesson. In addition, the researcher also prepared an observation sheet that will be given to the observer (classroom teacher) to observe the course of learning about explaining the effect of physical environment change on land (erosion, abrasion, flood and landslide) using constructivism approach. To deliver the subject matter the researcher also prepares the image media as well as the tools and materials to conduct the experiment.

Assessment of RPP is conducted through the assessment sheet of RPP with assessment aspect consisting of: (a) Clarity of formulation of learning objectives, (b) Selection of teaching materials, (c) Organizing teaching materials, (d) Selection of learning resources / media, (e) Clarity Learning process, (f) Learning technique, (g) Completeness of instrument. Based on observations made by the observer, the percentage score in the RPP assessment cycle I with an average of $80.3 \%$ with good qualifications. 
b. Implementation

Implementation in cycle I, this research is adapted constructivism approach according to steps according to according Nurhadi that is: (1) activation of existing knowledge, (2) acquisition of new knowledge, (3) new knowledge understanding, (4) application of knowledge and experience Obtained and (5) doing reflection. To observe the results of student learning, conducted through the assessment of the three domains, namely cognitive, affective and psychomotor assessment.

\section{c. Observation}

Based on observations made by observers on the implementation of learning in cycle I, the average value in the RPP assessment cycle I is $80.3 \%$ with good criteria, the average percentage of the value of the implementation of learning aspects of teachers is $78.5 \%$ with good qualifications, The average percentage of the value of the implementation of learning aspects of the students is $75 \%$ with good qualifications, and the percentage of student learning outcomes with an average of $79.6 \%$ with sufficient qualifications.

\section{d. Reflection}

Based on the results of observations and test results conducted, it can be concluded that the learning outcomes have not reached the expected category of success and completion criteria established. Thus, thematic learning with constructivism approach of the researchers continue on the second cycle better according to the design of the implementation of learning with constructivism approach.

\section{Cycle II}

\section{a. Planning}

Learning cycle II is given so that students can explain the effect of physical environment changes on land (erosion, abrasion, abnjir and landslide). The material in cycle II is a continuation of basic competence of cycle I with the material of flood and landslide by using constructivism approach. Learning cycle II is held in two meetings with each time allocation of $3 \times 35$ minutes.

Indicators expected at the first meeting are: 1) run the experiments of the flood process, 2) mention the definition of flood, 3 ) identify the causes of flooding on land and 4) give opinion in disabling prevention efforts from flood to the mainland. While the indicator that is expected at the second meeting is: 1) to run the experiment of landslide process, 2) mention the landslide, 3 ) to identify the cause of landslide on the land and 4) to give opinion in determining the prevention effort from the landslide to the land.

Based on the results of the actions of cycle I described above, in the second cycle of this action will be implemented namely: 1) Clarify the delivery of learning objectives so that students better understand the material to be taught, 2) each student in the group conduct experiments for full investigation With seriousness, 3) trying to maximize the use of time in learning in accordance with lesson plans, and 4) more motivate students to participate actively solve the LKS in the group.

b. Implementation

Implementation in cycle II, this research is adapted to constructivism approach in accordance with the steps according to Nurhadiyaitu: (1) activation of existing knowledge, (2) acquisition of new knowledge, (3) understanding of new knowledge, (4) application of knowledge and experience gained And (5) doing reflection. To observe student learning outcomes, it is done through the evaluation of three domains, namely cognitive, affective and psychomotor assessment.

\section{c. Observation}

This observation is carried out continuously from the beginning to the end activities. Based on observations made by observers on the implementation of learning in cycle II, the average value in the assessment of RPP cycle II is $87.4 \%$ with good criteria, the average percentage of the value of the implementation of learning aspects of teachers is $87.5 \%$ with very qualified Well, the average percentage of the value of the implementation of learning aspects of students in cycle II is $86.3 \%$ with excellent qualifications, and the percentage of student learning outcomes with an average of $86.3 \%$ with excellent qualifications.

d. Reflection 
From the reflection on cycle II, it is concluded that the expected learning objectives in cycle II have been achieved. Thus, the improvement of students' learning outcomes on science learning with constructivism approach is not continuing in the next cycle.

\section{DISCUSSION}

\section{1) Discussion of Cycle I}

Based on the note on the observation sheet and the discussion of the researcher with the observer, as for the observation of the researcher that is on the RPP assessment sheets of cycle I still have not achieved maximum results and need to be improved for the next cycle. Things that must be improved is the selection of teaching materials and organizing teaching materials. In the next learning teachers are expected to better understand the material for teaching materials that are taught precise and well organized.

Based on the results of the RPP assessment in cycle I, obtained the results of the assessment of RPP $78.5 \%$ in the first cycle of meeting I, whereas in cycle I meeting II obtained $82.1 \%$ results. So that the average result of RPP assessment in cycle $\mathrm{I}$ is $80,3 \%$ with the acquisition of success rate with good category.

At the time of implementation of learning using constructivism approach, there are some things that researchers observe and need to be improved in the next cycle are: (1) Teachers have not seen giving motivation to all students to be actively involved in group work, this deficiency is due to teachers focused on some students Just so that the other students are neglected. (2) Teachers have not been able to carry out the learning with constructivism approach in accordance with the allocation of time that has been planned by the teacher, this is because in learning activities many time teachers used to secure the class. (3) Many students have not been able to identify critical problem-related information, this is because the teacher has not been able to teach ynag learning nuanced active and fun. (4) Some students have not been able to solve the problem, this is because teachers have not been able to nurture the active participation of all learners in learning. And (5) Teachers still can not foster interpersonal relationships conducive because there are still students who lack friendship, and dominate the discussion, so that not all students work together in determining the problem solving.

The results of the implementation assessment of the aspects of teacher cycle I meeting I obtained an average of $71.4 \%$ and on the first cycle of meeting II obtained an average of $85.7 \%$. So that obtained the average implementation of the aspects of teachers cycle I is $78.5 \%$ with the acquisition category baik.Sedangkan assessment of the implementation of aspects of students I meeting I obtained an average of $71.4 \%$, and in cycle I meeting II obtained an average of $78,5 \%$. So obtained the average implementation of the aspects of students in the first cycle is $75 \%$ with the acquisition of good category.

While the assessment for student learning outcomes in the first cycle I meeting is $75 \%$ and on the first cycle II meeting is $82.2 \%$. So the average percentage of student learning outcomes in the first cycle is $79.6 \%$. Based on the above, concluded That the learning outcomes of students in the first cycle has not been completed or has not fulfilled the expected learning objectives. This shows that the learning outcomes in cycle I have not succeeded so it needs to be continued to the next cycle (Cycle II).

\section{2) Discussion of Cycle II}

Planning arranged in cycle II is the same as cycle I. The result of RPP assessment in cycle II of meeting I, the result of RPP assessment with average is $85,7 \%$, and assessment of RPP in Cycle II of meeting II obtained result of RPP with average $89.2 \%$. So the average result of RPP assessment in cycle II is $87,4 \%$ with success rate get very good category. Thus, the planning of learning made can be said to have obtained the maximum results.

While the assessment of the implementation of learning from the aspects of teachers in cycle II meeting I obtained an average of $87.5 \%$ and on the second cycle of meeting II obtained an average of $89.2 \%$. So the average assessment of teacher aspect of cycle II is obtained an average of $87.5 \%$ with the acquisition of very good category. This shows an increase from cycle I. Assessment of the implementation of student aspects of cycle II meeting 1 obtained an average of $82.1 \%$, and in cycle II meeting II obtained an average of $85.7 \%$. The assessment of the implementation of student aspects of cycle II is obtained an average of $83.9 \%$ with the 
acquisition category is very good as well. This indicates an increase from cycle I.

Assessment on student learning outcomes obtained average student learning outcomes cycle II meeting $\mathrm{I} 85.3 \%$ and average student learning outcomes II cycle II meeting $87.3 \%$. So that the end result of student learning in cycle II obtained by average percentage of result of student learning is $86,3 \%$. Based on the above described, it is concluded that the students' learning outcomes in cycle II have improved from learning outcomes in the previous cycle (Cycle I). Thus, the average has reached the KKM that has been set that is 80 . This shows that the learning outcomes in cycle II has reached $\mathrm{KKM}$, thus the research conducted is said to have succeeded To see the improvement of science learning implementation using constructivism approach in class IV SDN 11 Piai Tangah can be seen on the graph of the average value below:

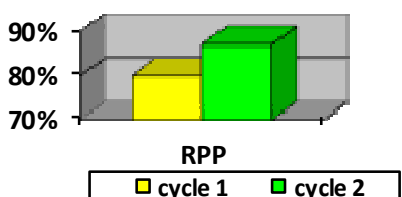

Figure 1 :Graphic of RPP assessment of cycle I and cycle II

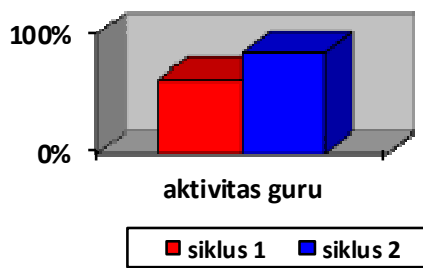

Figure 2 :

Graphic implementation of learning from the aspects of teachers cycle I and cycle II

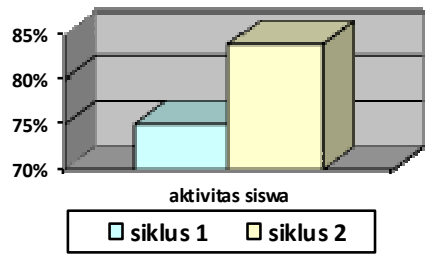

Figure 3 :Graphic implementation of learning from aspects of students cycle I and cycle II

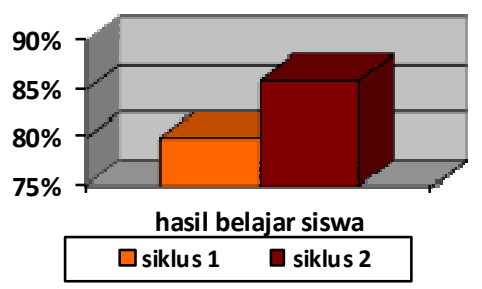

Figure 4 :Graphic increase student learning outcomes cycle I and cycle II

\section{CONCLUSIONS AND SUGGESTIONS}

Based on the research data above, it can be concluded as follows: (1) Implementation of science learning using constructivism approach implemented with steps: a) activation of existing knowledge, b) acquisition of new knowledge, c) understanding of new knowledge, d) Knowledge and experience gained and e) reflecting. (2) Recapitulation of the results of the implementation of learning cycle I also have increased in cycle II on the observation of the aspects of teacher cycle I obtained an average of $78.5 \%$ with good category to $87.5 \%$ in cycle II by obtaining the category very well. While on the aspect of students in the first cycle obtained an average of $75 \%$ with good category to $83.8 \%$ in cycle II by obtaining the category very well. (3) Student learning outcomes in science learning with constructivism approach in class IV SDN 11 Piai Tangah District Pauh Kota Padang has increased. This can be seen from the recapitulation of student learning outcomes cycle II is higher when compared with the recapitulation of learning outcomes cycle I is $79.6 \%$ increased to $86.3 \%$.

Based on the conclusion that has been mentioned above, the researcher suggests things as follows (1) Plan of Implementation of Science Lesson with constructivism approach worthy of consideration of teacher to be alternative learning approach in choosing the appropriate learning approach with subject matter to improve learning result. (2) Implementation of science learning with constructivism approach should be implemented by teacher in accordance with the steps that have been determined, because these steps can increase student's interest and student's cooperation in learning so that learning becomes fun and memorable for students. (3) If teachers want to apply constructivism approach, teachers should pay attention to material suitability. 


\section{REFERENCES}

[1] Nurhadi, et al. 2003. Contextual Learning And Its Implementation In KBK. Malang: State University of Malang.

[2] Rohani, Wanti. 2003. Conflicting Problem Solving. Malang: State University of Malang.

[3] Sanjaya, Wina. 2008. Learning StrategyOriented Learning Process Standards. Jakarta: Kencana.

[4] Usman Samantowa. 2011. Science Studies in Elementary School. Jakarta: PT index. 